\title{
Sapap3 Deletion Anomalously Activates Short-Term Endocannabinoid-Mediated Synaptic Plasticity
}

\author{
Meng Chen, ${ }^{1}$ Yehong Wan, ${ }^{1}$ Kristen Ade, ${ }^{1}$ Jonathan Ting, ${ }^{2}$ Guoping Feng, ${ }^{2,3}$ and Nicole Calakos ${ }^{1,2}$ \\ ${ }^{1}$ Center for Translational Neuroscience, Department of Medicine/Neurology, and ${ }^{2}$ Department of Neurobiology, Duke University Medical Center, Durham, \\ North Carolina 27710, and ${ }^{3} \mathrm{McG}$ overn Institute for Brain Research, Department of Brain and Cognitive Sciences, Massachusetts Institute of Technology, \\ Cambridge, Massachusetts 02139
}

Retrograde synaptic signaling by endocannabinoids (eCBs) is a widespread mechanism for activity-dependent inhibition of synaptic strength in the brain. Although prevalent, the conditions for eliciting eCB-mediated synaptic depression vary among brain circuits. As yet, relatively little is known about the molecular mechanisms underlying this variation, although the initial signaling events are likely dictated by postsynaptic proteins. SAP90/PSD-95-associated proteins (SAPAPs) are a family of postsynaptic proteins unique to excitatory synapses. Using Sapap3 knock-out (KO) mice, we find that, in the absence of SAPAP3, striatal medium spiny neuron (MSN) excitatory synapses exhibit eCB-mediated synaptic depression under conditions that do not normally activate this process. The anomalous synaptic plasticity requires type 5 metabotropic glutamate receptors (mGluR5s), which we find are dysregulated in Sapap3 K0 MSNs. Both surface expression and activity of mGluR5s are increased in Sapap3 KO MSNs, suggesting that enhanced mGluR5 activity may drive the anomalous synaptic plasticity. In direct support of this possibility, we find that, in wild-type (WT) MSNs, pharmacological enhancement of mGluR5 by a positive allosteric modulator is sufficient to reproduce the increased synaptic depression seen in Sapap3 K0 MSNs. The same pharmacologic treatment, however, fails to elicit further depression in KO MSNs. Under conditions that are sufficient to engage eCB-mediated synaptic depression in WT MSNs, Sapap3 deletion does not alter the magnitude of the response. These results identify a role for SAPAP3 in the regulation of postsynaptic mGluRs and eCB-mediated synaptic plasticity. SAPAPs, through their effect on mGluR activity, may serve as regulatory molecules gating the threshold for inducing eCB-mediated synaptic plasticity.

\section{Introduction}

The postsynaptic scaffold of proteins is important for synapse formation and dynamic modification of postsynaptic signaling. As such, these proteins can regulate neurotransmitter receptor activity. Scaffold proteins effectively link the major neurotransmitter receptors to intracellular signaling cascades and cytoskeletal elements (Sheng and Pak, 1999; Rumbaugh et al., 2003; Kim and Sheng, 2004). SAP90/PSD-95-associated proteins (SAPAPs; also referred to as guanylate kinase-associated proteins or GKAPs) are a family of postsynaptic scaffold proteins that localize to an intermediate layer of the PSD (Kim et al., 1997; Takeuchi et al., 1997; Valtschanoff and Weinberg, 2001) and are unique to excitatory synapses (Welch et al., 2004). By virtue of the protein

Received April 5, 2011; revised May 13, 2011; accepted May 16, 2011.

Author contributions: M.C., Y.W., K.A., G.F., and N.C. designed research; M.C., Y.W., K.A., and J.T. performed research; M.C., Y.W., K.A., and N.C. analyzed data; M.C., Y.W., K.A., J.T., G.F., and N.C. wrote the paper.

This work was supported by National Institute of Neurological Disorders and Stroke Grants T32NS051156 (K.A.) and NS064577 and NS054840 (N.C.), the Tourette Syndrome Association (N.C.), the Klingenstein Foundation (N.C.), NARSAD (N.C.), National Institute of Mental Health Grants F32MH084460 (J.T.) and MH081201 (G.F.), The Simons Foundation Autism Research Initiative (G.F.), and the Hartwell Foundation (G.F.). We gratefully acknowledge Samantha Tracy, David Pan, and Audrey Nelson for outstanding technical assistance, members of the Calakos lab for critical discussions, Serena Dudek, Sid Simon, and Ben Philpot for comments on the manuscript, Rui Costa and Andreas Zimmer for providing CB1R KO mice, and Bryan Roth, Noah Sciaky, and John Allen for critical support in BD pathway imaging experiments.

Correspondence should be addressed to Nicole Calakos, P.0. Box 2900, Duke University Medical Center, Durham, NC27710. E-mail: nicole.calakos@duke.edu.

DOI:10.1523/JNEUROSCI.1701-11.2011

Copyright $\odot 2011$ the authors $\quad 0270-6474 / 11 / 319563-11 \$ 15.00 / 0$ complexes in which SAPAPs have been identified in vitro (Naisbitt et al., 1997; Boeckers et al., 1999; Tu et al., 1999; Hirao et al., 2000; Romorini et al., 2004), SAPAPs might influence the activity of ionotropic and metabotropic glutamate receptors and/or the intracellular signaling cascades with which these receptors interact. However, to date, very little is known about whether SAPAPs influence synaptic activity.

SAPAPs are encoded by a family of four genes that are widely expressed throughout the nervous system (Takeuchi et al., 1997; Kindler et al., 2004; Welch et al., 2004). In prior studies, we have shown that Sapap3 KO mice have obsessive compulsive disorder (OCD)-like behaviors (excessive self-grooming, facial lesions, anxiety-like behaviors, and therapeutic response to fluoxetine) and altered basal striatal neurotransmission (Welch et al., 2007). SAPAP3 is the only SAPAP that is highly expressed in the striatum (Welch et al., 2004, 2007). Viral rescue of SAPAP3 expression in the striatum of Sapap3 KO mice prevents the behavioral abnormalities and reverses the striatal neurotransmission defects demonstrating that striatal loss of SAPAP3 activity is critical for the expression of the pathological behaviors. These findings indicate that, at striatal synapses, SAPAP3 has little functional redundancy with other SAPAPs. Accordingly, the study of excitatory synaptic function in the striatum of Sapap3 KO mice provides a unique platform for elucidating the role of SAPAPs in synaptic function.

In this study, we investigate excitatory synaptic transmission of striatal medium spiny neurons (MSNs) in acute brain slices 
from Sapap3 KO mice. We find that loss of SAPAP3 results in abnormal endocannabinoid-mediated synaptic plasticity. Striatal excitatory synapses of Sapap $3 \mathrm{KO}$ mice engage eCB-mediated, short-term synaptic depression under conditions that are insufficient to activate this process in wild-type (WT) synapses. This is likely due to an increase in group 1 mGluR activity. Group 1 mGluR activity and mGluR5 surface expression are increased in Sapap3 KO MSNs. Pharmacological enhancement of mGluR5 activity in WT MSNs mimics the abnormal synaptic depression of KO MSNs. These findings provide the first functional evidence for a role of SAPAP3 in the regulation of postsynaptic mGluRs and eCB-mediated synaptic plasticity.

\section{Materials and Methods}

Animals. Generation of Sapap3 KO mice, Drd1a-tdTomato (D1) transgenic mice, and Drd2-EGFP (D2) transgenic mice was described previously (Gong et al., 2003; Welch et al., 2007; Shuen et al., 2008). Experimental mice were the progeny of Sapap $3^{+/-}$by Sapap $3^{+/-}$breedings in which only one of the parents expressed the Drdla-tdTomato or Drd2-EGFP transgenes so that no experimental subjects were homozygous for the transgenic fluorescent markers. In experiments testing genotype effects, littermate control animals were used. All experiments were performed and analyzed with the experimenter blind to the identity of the experimental variable being tested (i.e., genotype or drug effect). Type 1 endocannabinoid receptor (CB1R) KO mice were provided by Dr. Rui Costa (Champalimaud Neuroscience Programme, Oeiras, Portugal) and generated by Dr. Andreas Zimmer (University of Bonn, Bonn, Germany) (Zimmer et al., 1999). All animal procedures were done according to protocols approved by the Institutional Animal Care and Use Committee of Duke University.

Brain slice preparation. Coronal brain slices $(300 \mu \mathrm{m})$ were used for all recording and imaging experiments. In extracellular recording experiments, Sapap $3^{+/+}$and Sapap $3^{-/-}$mice aged 3-12 weeks and Sapap $3^{-/-} / C B 1 R^{-1-}$ and Sapap $3^{-/-} / \mathrm{CB} \mathrm{R}^{+/+}$mice aged $24-52$ weeks were used. Sapap $3^{+/+}$ and Sapap $3^{-/-}$mice coexpressing Drd1a-tdTomato and/or Drd2-EGFP transgenes were used for whole-cell recording experiments ( 3 weeks old) and calcium dye imaging experiments ( 2.5 weeks old). All electrophysiological results are from 3-week-old mice unless specified otherwise. Young mice were anesthetized with isoflurane before decapitation. Older mice ( $>8$ weeks old) were anesthetized with tribromoethanol and transcardially perfused with oxygenated, ice-cold artificial CSF (ACSF) before decapitation. The brains were rapidly removed and sliced in oxygenated, ice-cold sucrose ACSF with a Vibratome 1500 (Leica). Sucrose ACSF contained the following (in mM): 194 sucrose, $30 \mathrm{NaCl}, 2.5$ $\mathrm{KCl}, 1.2 \mathrm{NaH}_{2} \mathrm{PO}_{4}, 0.2 \mathrm{CaCl}_{2}, 2 \mathrm{MgCl}_{2}, 26 \mathrm{NaHCO}_{3}$, and $10 \mathrm{D}-(+)-$ glucose (Choi and Lovinger, 1997). Slices recovered in standard ACSF saturated with $95 \% \mathrm{O}_{2}$ and $5 \% \mathrm{CO}_{2}$ at room temperature for at least $1 \mathrm{~h}$ before recording. Standard ACSF contained the following (in mM): 124 $\mathrm{NaCl}, 2.5 \mathrm{KCl}, 1.2 \mathrm{NaH}_{2} \mathrm{PO}_{4}, 2 \mathrm{CaCl} 2,1 \mathrm{MgCl} 2,26 \mathrm{NaHCO} 3$, and 10 $\mathrm{D}-(+)$-glucose.

Electrophysiology. Slices were continuously perfused at a constant rate of $2-3 \mathrm{ml} / \mathrm{min}$ with standard ACSF saturated with $95 \% \mathrm{O}_{2}$ and $5 \% \mathrm{CO}_{2}$. Recordings were made in the dorsolateral region of striatum and stimulation was given in the corpus callosum. Stimuli were programmed by pClamp software (Molecular Devices) and delivered using an Iso-flex stimulus isolator (A.M.P.I.) and a twisted tungsten wire bipolar electrode (A-M Systems; outer diameter, 0.005 inches) (Lovinger and McCool, 1995). A MultiClamp 700B amplifier and DigiData 1322A (Molecular Devices) were used for signal acquisition. Signals were sampled at $20 \mathrm{kHz}$ and low-pass filtered at $2 \mathrm{kHz}$. Picrotoxin $(50 \mu \mathrm{M})$ was present in all experiments to exclude $\mathrm{GABA}_{\mathrm{A}}$ inhibitory synaptic activity. Experiments were performed at $30-32^{\circ} \mathrm{C}$ unless specified otherwise.

For field potential recordings, the recording pipette was filled with $2 \mathrm{M}$ $\mathrm{NaCl}$, and pipette resistance was $\sim 1-3 \mathrm{M} \Omega$. The basal stimulation intensity was selected by identifying the lowest intensity that elicited the maximal field potential amplitude determined by an input/output survey performed at room temperature. Field potential responses were evoked using paired stimuli [interpulse interval (IPI), $50 \mathrm{~ms}$ ]. For whole-cell, voltage-clamp recordings, membrane potential was held at $-70 \mathrm{mV}$ unless specified otherwise. Recording pipettes had a resistance of 2.5-4.5 $\mathrm{M} \Omega$ when filled with internal pipette solution containing the following (in mM): 120 Cs- $\mathrm{MeSO}_{3}, 5 \mathrm{NaCl}, 10$ tetraethyl ammonium chloride, 10 HEPES, 0.3 EGTA, 4 MgATP, $0.3 \mathrm{Na}_{3} \mathrm{GTP}$, and 5 QX314-Cl. The osmolarity was adjusted to $\sim 290 \mathrm{mOsm} / \mathrm{L}$ with sucrose, and the $\mathrm{pH}$ was adjusted to 7.3 with cesium hydroxide. Cells were visualized with a $40 \times$ water-immersion objective (LUMPlanFI, $40 \times / 0.80$ water immersion) under an Olympus BX51WI microscope equipped with infrared differential interference contrast optics, reflected fluorescence system, and OLY-150 camera (Olympus). Series resistance $\left(R_{\mathrm{s}}\right)$ was monitored continuously by a $5 \mathrm{mV}$ voltage step following each pair of evoked EPSCs (eEPSCs). Average series resistance $\left(R_{\mathrm{s}}\right)$, input membrane resistance $\left(R_{\mathrm{m}}\right)$, holding current $\left(I_{\text {hold }}\right)$, and membrane capacitance $\left(C_{\mathrm{m}}\right)$ were as follows: $R_{\mathrm{s}}$, WT, $16.8 \pm 2.0 \mathrm{M} \Omega, n=13 ; \mathrm{KO}, 20.3 \pm 1.6 \mathrm{M} \Omega, n=14 ; p=0.2 ; R_{\mathrm{m}}, \mathrm{WT}$, $240 \pm 20 \mathrm{M} \Omega, n=13 ; \mathrm{KO}, 307 \pm 35 \mathrm{M} \Omega, n=14 ; p=0.1 ; I_{\text {hold }}$, WT, $-27 \pm 9 \mathrm{pA}, n=13 ; \mathrm{KO},-13 \pm 7 \mathrm{pA}, n=14 ; p=0.2 ; C_{\mathrm{m}}, \mathrm{WT}, 100 \pm$ $4 \mathrm{pF}, n=13 ; \mathrm{KO}, 87 \pm 6 \mathrm{pF}, n=14 ; p=0.1$. Recordings with $R_{\mathrm{s}}>30$ $\mathrm{M} \Omega$ or a change of $>20 \%$ were excluded. EPSCs were evoked using paired stimuli (IPI, $50 \mathrm{~ms}$ ). The basal stimulation intensity was adjusted to elicit baseline EPSC amplitudes between 200 and 400 pA. Paired-pulse ratios (PPRs) were calculated by the ratio of the averaged peak of the second EPSC [or population spike (PS)] to the averaged peak of the first EPSC (or PS) for each $60 \mathrm{~s}$ time period. All responses were normalized to the average value during the $7.5 \mathrm{~min}$ period of $90 \mathrm{~s}$ interval stimulation just before stimulation interval change ("baseline"). Summary bar graphs of activity-dependent depression protocol data present the average value during the last $10 \mathrm{~min}$ of $10 \mathrm{~s}$ stimulation normalized to baseline. The dose eliciting the submaximal effect of $(R)$ - $(+)$-[2,3-dihydro-5-methyl-3- (4-morpholinylmethyl)pyrrolo[1,2,3-de]-1,4-benzoxazin-6-yl]-1- naphthalenylmethanone mesylate (WIN 55212-2) was identified in pilot experiments that tested a range of drug concentrations $(0.3-6 \mu \mathrm{M})$ to determine a concentration of WIN 55212-2 that produced a submaximal level of depression. At $6 \mu \mathrm{M}$, a maximal degree of depression (eEPSC amplitude relative to baseline, $55 \pm 9 \% ; n=4$ ) was observed. Long-term depression (LTD) experiments were performed at $30 \mathrm{~s}$ basal stimulation interval. LTD was induced by four $100 \mathrm{~Hz}$ trains of $1 \mathrm{~s}$ duration paired with depolarization to $0 \mathrm{mV}$ (Choi and Lovinger, 1997; Kreitzer and Malenka, 2005). The intertrain interval was $10 \mathrm{~s}$. Stimulus intensity during high-frequency stimulation (HFS) was increased to the minimum intensity that evoked the maximal field response (Kreitzer and Malenka, 2005). Sample traces are the average of five consecutive sweeps. In all experiments reporting response amplitude, the values refer to the amplitude of the first response elicited by the pair of $50 \mathrm{~ms}$ IPI stimuli.

Calcium imaging in acute brain slices. Acute coronal brain slices (300 $\mu \mathrm{M}$ ) were prepared from postnatal day 17 (P17)-P19 WT and KO littermates expressing both Drd1a-tdTomato and Drd2-EGFP transgenes. One hour after sectioning, slices were transferred to incubation chambers containing $3 \mathrm{ml}$ standard ACSF equilibrated with $95 \% \mathrm{O}_{2}$ and 5\% $\mathrm{CO}_{2}$ and maintained at $36^{\circ} \mathrm{C}$ for calcium indicator bulk loading (MacLean and Yuste, 2009). The fura-2 AM dye solution was prepared daily by dissolving $50 \mu \mathrm{g}$ of fura-2 AM (Invitrogen) in $22 \mu \mathrm{l} \mathrm{DMSO/Pluronic}$ F-127 (0.02\%; Invitrogen). Nine microliters of filtered dye solution were added to each incubation chamber for bulk loading of the slices. After 30 $\mathrm{min}$, the slices were transferred to a holding chamber containing standard ACSF at room temperature for at least 45 min before imaging. All imaging was completed within $3 \mathrm{~h}$ of the loading procedure. Dye preparation as well as loading, recovery, and imaging of the slices were performed in the dark to minimize photobleaching of the fura-2 AM.

After recovery from the loading procedure, slices were transferred to the imaging chamber on an upright Ultima microscope (Prairie Technologies). Fields of view $50 \pm 20 \mu \mathrm{m}$ deep in the dorsolateral striatum were selected for imaging, and a femtosecond laser (Chameleon Ultra I; Coherent Technologies) was used to excite the transgenic and calcium indicator fluorophores. The laser wavelength was tuned to $1040 \mathrm{~nm}$ for tdTomato and $900 \mathrm{~nm}$ for EGFP. Fura-2 AM was imaged with a single wavelength $(800 \mathrm{~nm})$ that predominately excites fura-2 in a calcium-free state (Wokosin et al., 2004; Nikolenko et al., 2008). Fluorescence images were acquired using Prairie View image acquisition software (Prairie 
A
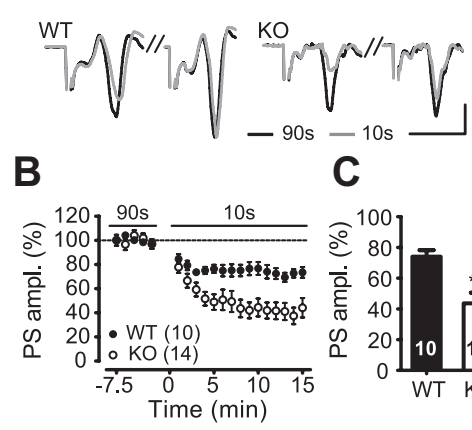

C
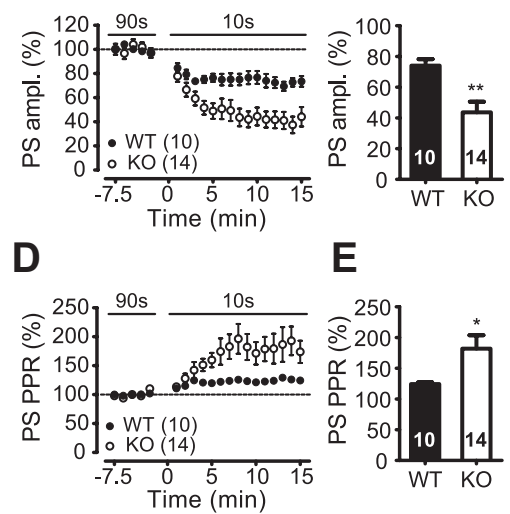

$E$

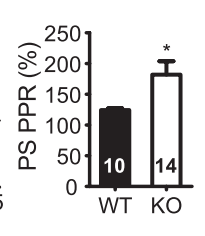

$\mathbf{F}$

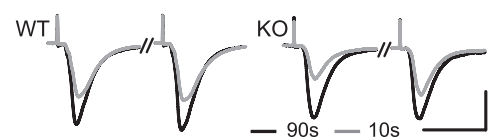

$\mathbf{H}$
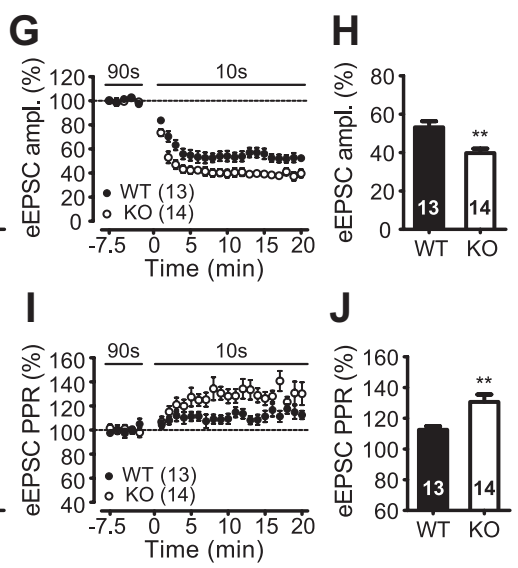

Figure 1. Activity-dependent synaptic depression of MSN excitatory synapses is enhanced in Sapap3 K0 mice. $\boldsymbol{A}-\boldsymbol{E}$, A decrease in stimulation interval from $90 \mathrm{~s}$ to 10 s causes greater depression of field PS responses in Sapap3 $\mathrm{KO}$ mice than WT controls. Each stimulation consists of a pair of pulses $50 \mathrm{~ms}$ apart. $\boldsymbol{A}$, Sample traces of evoked paired stimuli illustrate typical responses at $90 \mathrm{~s}$ and $10 \mathrm{~s}$ stimulation interval periods in WT and KO mice. $\boldsymbol{B}$, Time course plot displays relative change in PS amplitude from $90 \mathrm{~s}$ stimulation interval period to $10 \mathrm{~s} \mathrm{stimulation} \mathrm{interval} \mathrm{period} \mathrm{(} p=0.005$; rmANOVA). C, Summary bar graph compares WT and K0 average values over last $10 \mathrm{~min}$ of 10 s interval stimulation normalized to baseline period ( $p=0.003 ; t$ test). $\boldsymbol{D}, \boldsymbol{E}$, Time course plot (D) and bar graph $(\boldsymbol{E})$ demonstrate a concomitant activity-dependent increase in PPR of PS amplitude in Sapap3 K0 mice $(p=$ 0.036, rmANOVA; $p=0.038, t$ test). $\boldsymbol{F}$-J, Whole-cell, voltage-clamp recordings of eEPSCs from D2 MSNs show greater activitydependent synaptic depression in Sapap 3 KO than WT mice. $\boldsymbol{F}$, Sample traces illustrate typical responses at 90 s and 10 s stimulation interval periods in WT and KO mice. $\boldsymbol{G}, \boldsymbol{H}$, Time course plot $(\boldsymbol{G})$ and summary bar graph $(\boldsymbol{H})$ of the normalized eEPSC amplitude ( $p=$ 0.005 , rmANOVA; $p=0.002, t$ test). $I, J$, Time course plot $(I)$ and summary bar graph $(J)$ demonstrate a concomitant increase in PPR of eEPSC when stimulation interval is decreased in D2 MSNs of Sapap3 K0 mice ( $p=0.034$, rmANOVA; $p=$ 0.003 , $t$ test). Calibration: $A, 5 \mathrm{~ms}, 0.5 \mathrm{mV} ; \boldsymbol{F}, 20 \mathrm{~ms}, 200 \mathrm{pA} .{ }^{*} p<0.05 ;{ }^{* *} p<0.01$.

Technologies). Emitted photons were collected by a $20 \times, 1.0 \mathrm{NA}$ XLUMPlanFL $\mathrm{N}$ water-immersion objective and an Aplanat/Acrhromatic 1.4 NA oil-immersion condenser (Olympus), and redirected to both epifluorescence and transfluorescence photomultiplier systems where emitted light was split into two channels by a $575 \mathrm{~nm}$ dichroic mirror. EGFP and fura-2 AM signals were imaged a 525/70 $\mathrm{nm}$ bandpass filter. TdTomato signal was imaged using a $607 / 45 \mathrm{~nm}$ bandpass filter.

After acquiring EGFP and tdTomato reference images, fura- 2 fluorescence raster-scan images were acquired at a rate of $1 \mathrm{~Hz}$ throughout the experimental procedure, which included a no-drug baseline (10 s duration) and response to $100 \mu \mathrm{M}(R S)$-3,5-dihydroxyphenylglycine (DHPG; 20 s period following drug application). All solutions used during imaging contained standard ACSF and the sodium channel blocker tetrodotoxin $(1 \mu \mathrm{M})$. Slices received continuous bath and local perfusion of solutions at room temperature throughout the imaging procedure. Drugs were applied locally via a VC-6M Mini-Valve System-controlled perfusion system (Warner Instruments). NMDA ( $500 \mu \mathrm{M})$ was applied at the end of each experiment as a positive control for correct placement of local perfusion tube.

Fluo-4 calcium imaging of corticostriatal cocultured neurons. Corticostriatal cocultures were prepared from P1 littermate Sapap3 WT and KO mice. Following decapitation, striatal and cortical tissues were dissected in ice-cold dissection solution containing the following (in $\mathrm{mM}$ ): 161 $\mathrm{NaCl}, 5 \mathrm{KCl}, 0.5 \mathrm{MgSO}_{4}, 2.9 \mathrm{CaCl}_{2}, 5$ HEPES, $5.6 \mathrm{D}-(+)$-glucose, and 0.006 phenol red at $\mathrm{pH}$ 7.4. Tissue was enzymatically digested for $20 \mathrm{~min}$ at $37^{\circ} \mathrm{C}$ in dissection solution, which also contained $0.2 \mathrm{mg} / \mathrm{ml} \mathrm{L}$-cysteine; $1 \mathrm{~mm} \mathrm{CaCl}_{2} ; 0.5$ mM EDTA, $\mathrm{pH} 8 ; 4,000$ units/ml DNase I from bovine pancreas (all from Sigma-Aldrich); and 10 units/ml papain (Worthington Biochemical), $\mathrm{pH}$ 8.0. The digestion was inactivated by removal of the supernatant and addition of dissection solution containing 2.5 $\mathrm{mg} / \mathrm{ml}$ bovine serum albumin (BSA), $2.5 \mathrm{mg} / \mathrm{ml}$ trypsin inhibitor, and 4,000 units/ml DNase I from bovine pancreas (all from Sigma-Aldrich). Tissue was triturated with low-resistance, fire-polished Pasteur pipettes, passed through $70 \mu \mathrm{m}$ cell sieves (BD Biosciences), and pelleted at $200 \times g$ for $8 \mathrm{~min}$ before resuspending in serum media that consisted of: Minimum Essential Medium with Earle's salts without L-glutamine (Sigma-Aldrich), 5\% fetal bovine serum, $25 \mathrm{~mm}$ glucose, and $0.02 \%$ Mito+ Serum Extender (BD Biosciences). Cortical and striatal cells were plated at a 1:1 ratio at a density of 16 to $20 \times 10^{3}$ cells/well on Greiner 96 well poly-D-lysine-coated glassbottom plates (Sigma-Aldrich) in 80\% Neurobasal A media (NBA) containing $1 \times$ B-27 serum-free supplement (Invitrogen) and $1 X$ GlutaMAX-1 supplement (Invitrogen) and $20 \%$ serum media.

On the day of imaging (DIV 15-17), cultures received a $20 \%$ media exchange with NBA containing 100 mM HEPES, pH 7.4, and were transferred to the cell imaging facility where they were imaged using the BD Pathway 855 high-content, high-throughput imaging system and an Olympus Plan Fluo 0.75 NA, 20× objective. All experiments were performed at $36-37^{\circ} \mathrm{C}$. Cells were loaded with fluorometric imaging plate reader (FLIPR) dye for $1 \mathrm{~h}$ by replacing media with $90 \mu \mathrm{l}$ of filtered imaging buffer containing $1 \times$ Hank's balanced salt solution (without phenol red or sodium bicarbonate), $4 \mathrm{~mm}$ HEPES, $0.5 \mathrm{mg} / \mathrm{ml}$ probenecid, $0.1 \mathrm{mg} / \mathrm{ml}$ ascorbic acid, $2 \mu \mathrm{M}$ tetrodotoxin citrate (TTX), and $1.5 \times$ FLIPR calcium assay kit component A (Invitrogen), pH 7.4. Cells were maintained at $37^{\circ} \mathrm{C}$ during both dye loading and imaging. Imaging was completed within $1 \mathrm{~h}$ following completion of dye loading. Fluorescent images were obtained at $1 \mathrm{~Hz}$ during a no-drug baseline (10 s duration), response to $100 \mu \mathrm{M}$ DHPG (20 s period following drug application), and subsequent response to 1-2 mM NMDA (20 s period), the latter done to identify live neurons.

Calcium dye image analysis. Image processing for both fura- $2 \mathrm{AM}$ and Fluo-4 dye experiments was performed using Image J software (http:// rsb.info.nih.gov/ij/). For acute slice data, regions of interest (ROIs) with a somatic area of $17-53 \mu \mathrm{m}^{2}$ were selected from the tdTomato image (for D1 MSNs) or the EGFP image (for D2 MSNs). For the culture data, somatic ROIs from MSNs were selected from maximum intensity projections and cell type was confirmed using morphological features observed in the corresponding transmitted light images (somatic diameter, $\leq 14 \mu \mathrm{m}$; demonstrated somatic circularity, $\geq 0.8$ ). Morphological selection criteria were derived from EGFP-fluorescent cells in striatal cultures prepared from Drd2-EGFP transgenic mice.

Fluorescence for all ROIs in both the culture and acute slice was normalized to the mean fluorescence intensity of the ROI during the $10 \mathrm{~s}$ baseline period preceding application of DHPG and is expressed as the change in fluorescence/mean baseline fluorescence $(\Delta F / F)$. Cells were excluded from analysis if they demonstrated an unstable baseline fluorescence intensity (SD of $>0.03 \Delta F / F$ ) or showed no positive physiological response to the NMDA application (max response of $<0.1 \Delta F / F$ for cultures; $<0.15 \Delta F / F$ for acute slices) These objective criteria resulted in exclusion of $10 \%$ of WT D1, 9\% WT D2, 14\% KO D1, and 11\% KO D2 cells for the acute slice data. WT and KO culture data were each derived from 13 wells and three separate culture preparations. Acute slice data were derived from seven slices from three animals (WT) and eight slices from two animals $(\mathrm{KO})$. Additionally, $<1.5 \%$ of transgene positive cells in the acute slices expressed both EGFP and tdTomato, and, when present, such cells were excluded from the analysis. Data are represented as the mean maximal response (within $20 \mathrm{~s}$ after DHPG application) \pm SEM. The $n$ values represent the number of cells per condition.

Immunocytochemistry and image analysis. Corticostriatal cocultures prepared as described above were used to measure the surface expression 
of mGluR5. On DIV 13-14, cultures were fixed with $4 \%$ paraformaldehyde in $4 \%$ sucrose for $15 \mathrm{~min}$ at room temperature. Cultures were then rinsed with PBS and blocked in PBS with $0.2 \%$ gelatin, $2 \%$ BSA, $2 \%$ glycine, and $50 \mathrm{~mm}$ $\mathrm{NH}_{4} \mathrm{Cl}$ for $30 \mathrm{~min}$ at room temperature. Cultures were stained with anti-mGluR5 $\mathrm{N}$-terminus rabbit polyclonal antibodies (1:50; AGC-007; Alomone Labs) overnight at $4^{\circ} \mathrm{C}$. Cultures were then rinsed in $\mathrm{PBS}$ and permeabilized in PBS with $0.25 \%$ Triton X-100 for $5 \mathrm{~min}$ at room temperature. Cultures were rinsed with PBS, blocked, and then incubated with monoclonal antibodies against rat DARPP-32 (1:40; MAB4230; R \& D Systems), a marker used to identify MSNs, for $2 \mathrm{~h}$ at room temperature. Cultures were then rinsed and incubated with the appropriate secondary antibodies (Alexa Fluor 568-conjugated goat anti-rabbit IgG, 1:800, Invitrogen; Cy5-conjugated donkey anti-rat IgG, 1:200, Jackson ImmunoResearch) for $2 \mathrm{~h}$ at room temperature. After the final washing with PBS, Fluoromount-G (Southern Biotech) was used to mount coverslips. Surface immunostaining, conditions were confirmed by lack of staining with DARPP-32 when incubated under nonpermeabilizing conditions. Images were collected with a $40 \times$ objective on an LSM 510 confocal microscope (Zeiss). Alexa Fluor 568 dye was excited with a $561 \mathrm{~nm}$ diode laser. Cy5 dye was excited with a $633 \mathrm{~nm}$ HeNe laser. No cross talk between channels was detected under these settings. All mGluR5 images were collected under identical acquisition conditions and subsaturating conditions. Images were collected from three independent batches of cultures with two coverslips per group for each batch. Six images were taken from each coverslip. Two dendritic regions $(\sim 40 \mu \mathrm{m}$ long) were selected for analysis by a separate experimenter who used only the DARPP-32immunostained and transmitted light images for selection. Dendrites were selected if they were clearly part of a cell with high-intensity DARPP-32 staining (an indicator of medium spiny neurons) and did not have other dendrites overlying. For quantitative analysis, the average mGluR5 immunostaining intensity (total intensity/total area of dendritic region, in arbitrary units per pixel) was measured on DARPP-32-positive dendritic regions with MetaMorph software (Molecular Devices). In data not shown, an analysis of total mGluR5 intensity normalized to the total vGluT1 (Synaptic Systems; catalog \#135511) intensity in dendritic regions of interest resulted in similar statistically significant conclusions.

Drugs. All drugs were made as concentrated stock solutions and diluted in ACSF to their final concentration on the experiment day. $\mathrm{N}$-(piperidin-1yl)-5-(4-iodophenyl)-1-(2,4-dichlorophenyl)-4-methyl-1 H-pyrazole-3carboxamide (AM251), WIN 55212-2, 2-methyl-6-(phenylethynyl)pyridine hydrochloride (MPEP), DHPG, 3-cyano- $\mathrm{N}$-(1,3-diphenyl-1 $\mathrm{H}$ pyrazol-5-yl) benzamide (CDPPB), TTX, NMDA, and nifedipine were purchased from Tocris Bioscience. Picrotoxin and BSA were purchased from Sigma. BSA (0.05\%) was used as a carrier for AM251, WIN 55212-2, and CDPPB experiments and their corresponding vehicle control experiments. For AM251 experiments (see Fig. 2), slices were preincubated with AM251 for $1 \mathrm{~h}$ before recording and continuously perfused with antagonist during recording. All other drug treatments were applied during bath perfusion only.

Statistical analysis. All electrophysiological recording data were analyzed by Clampfit 10.0 software (Molecular Devices). The peak amplitude of field popu-
B

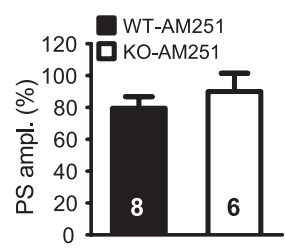

E

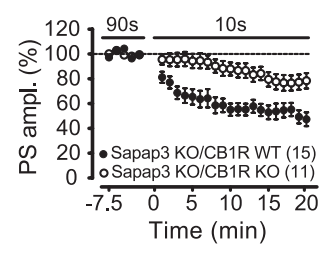

$\mathrm{H}$

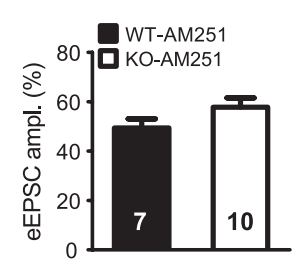

C

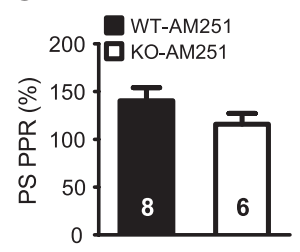

$\mathbf{F}$

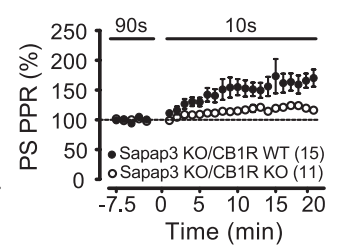

I

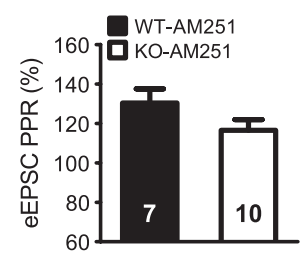

K

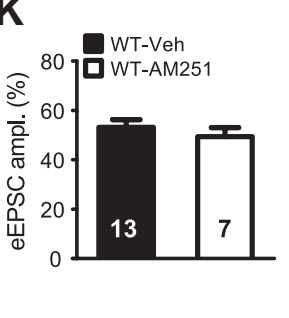

$\mathbf{L}$

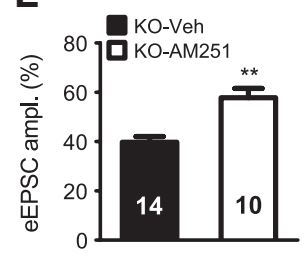

Figure 2. Excessive synaptic depression in Sарар3 $\mathrm{KO}$ mice is mediated by endocannabinoid signaling. $\boldsymbol{A}$, Sample traces illustrate

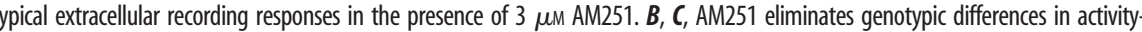
activity-dependent depression of PS amplitude in Sapap $3 \mathrm{KO}$ mice $(p=0.001$; rmANOVA). $\boldsymbol{F}$, (BIR gene deletion significantly reduces ativitydependentincrease in PS PPR in Sapap3 KO mice ( $p=0.023$; rmANOVA). G, Sampletracesillustratetypical eEPSC responses in the presence of $3 \mu \mathrm{m}$ In the presence of $3 \mu \mathrm{mAM} 251$, there is no difference in activity-dependent synaptic depression of D2 MSN eEPSCs between WT and KO 137 synaptic responses ( $p=0.791 ;$ rmANOVA). The effects of WIN 55212-2 were tested at room temperature and 90 s stimulation interval to avoid

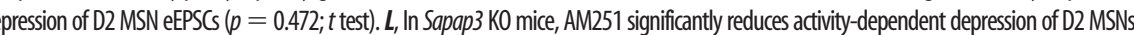
eEPSCs ( $p=0.0003, t$ test). Calibration: $\boldsymbol{A}, 5 \mathrm{~ms}, 0.5 \mathrm{mV} ; \boldsymbol{G}, 20 \mathrm{~ms}, 200 \mathrm{pA} .{ }^{* *} p<0.01$.

lation spikes and evoked ESPCs was measured and data were transferred to Microsoft Excel and GraphPad Prism for analysis and graphing. Data are presented as mean \pm SEM, and the $n$ value given for each experiment refers to the number of cells analyzed unless noted otherwise. Bar graph data present the average value of the response during the last $10 \mathrm{~min}$ of the $10 \mathrm{~s}$ stimulation interval period normalized to the baseline response value. Two-way repeated measures ANOVA (rmANOVA) was performed for the entire time course before post hoc comparisons were made with Student's $t$ test or the Mann-Whitney rank test (JMP version 8.0 software; SAS institute). The significance level for all tests was $p<0.05$. For linear regression analysis, $R^{2}$ values are reported.

\section{Results}

Activity-dependent synaptic depression of striatal excitatory synapses is increased in Sapap3 KO mice

Abnormal activity-dependent depression in Sapap3 KO mice was initially suspected because of an observation that evoked extracellular field potentials in Sapap3 KO striatal slices were prefer- 

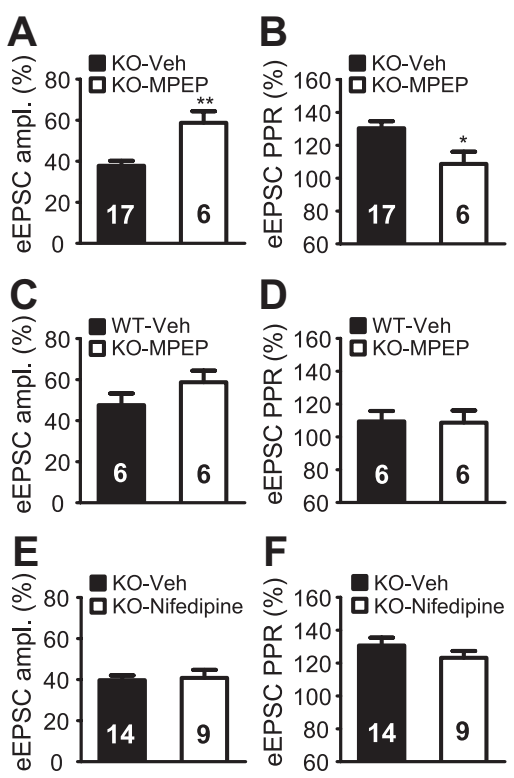

Figure 3. Anomalous eCB-mediated synaptic depression at Sapap3 $\mathrm{KO}$ synapses requires mGluR5. A, Type $5 \mathrm{mGluR}$ antagonist, MPEP $(40 \mu \mathrm{m})$ significantly reduces activity-dependent depression of D2 MSN eEPSCs in Sapap3 KO mice ( $p=0.001 ; t$ test). $\boldsymbol{B}$, MPEP reduces the activity-dependent PPR increase in D2 MSN eEPSCS of Sapap3 K0 mice ( $p=0.018 ; t$ test). C, $\boldsymbol{D}$, Activity-dependent synaptic depression $(\boldsymbol{C})$ and PRR $(\boldsymbol{D})$ in MPEP-treated Sapap3 KO MSNs are similar to untreated WT D2 MSNs, ( $p=0.193$ and 0.942 , respectively; $t$ test). $\boldsymbol{E}, \boldsymbol{F}$, L-type calcium channel antagonist nifedipine $(10 \mu \mathrm{m})$ has no effect on activity-dependent changes in synaptic depression $(\boldsymbol{E})$ or PPR $(\boldsymbol{F})$ of D2 MSN eEPSC in Sapap3 K0 mice ( $p=0.801$ and 0.291, respectively; $t$ test). ${ }^{*} p<0.05 ;{ }^{* *} p<0.01$.

entially unstable (rundown) or lost. However, stable responses could be obtained for both WT and KO genotypes by reducing the frequency of stimulation, suggesting that rundown of responses in KO brain slices might be caused by activity-dependent synaptic depression. To test this hypothesis, we evaluated the changes in field potential PS amplitude and PS PPR that occurred as a consequence of increasing stimulation rate. Stable baseline PS field potential responses were first obtained in dorsolateral striatum by stimulating each $90 \mathrm{~s}$. Thereafter, the stimulation interval was reduced to $10 \mathrm{~s}$. In response to the reduction in stimulation interval, PS amplitude in Sapap3 KO slices depressed markedly (PS amplitude relative to baseline, WT, $74 \pm 4 \%, n=$ 10 ; KO, $43 \pm 7 \%, n=14 ; p=0.003, t$ test) (Fig. $1 A-C$ ). Concomitantly, the PPR of the PS amplitude increased (PPR relative to baseline, WT, $124 \pm 3 \%, n=10 ; \mathrm{KO}, 182 \pm 22 \%, n=14 ; p=$ $0.038, t$ test) (Fig. 1D,E). These findings were also present and of similar magnitude in mature adult mice ( 8 weeks and older; PS amplitude relative to baseline, WT, $71 \pm 5 \%, n=10 ; \mathrm{KO}, 40 \pm$ $4 \%, n=11 ; p=0.0002, t$ test). Although the amplitudes of basal field potential responses were lower in Sapap3 KO mice than WT mice (baseline PS amplitude, WT, $-1.2 \pm 0.1 \mathrm{mV}, n=20$; KO, $-0.9 \pm 0.1 \mathrm{mV}, n=25 ; p=0.035, t$ test), there was no correlation between the degree of activity-dependent depression and initial PS amplitude or PPR (percentage of depression vs initial PS amplitude, WT, $R^{2}=0.077 ; \mathrm{KO}, R^{2}=0.0004$; percentage depression vs initial PPR, WT, $R^{2}=0.002 ; \mathrm{KO}, R^{2}=0.110$ ).

Because the PPR of synaptic responses varies inversely with release probability, the frequency-dependent increase in PPR of Sapap3 KO PS responses suggests that a decrease in presynaptic release probability may underlie the PS depression. However, PS can also be influenced by nonsynaptic contributions. To isolate the synaptic contributions, whole-cell, voltage-clamp recordings were performed. In 3-week-old mice, whole-cell, voltage-clamp recordings were obtained from defined subpopulations of MSNs based on their expression of BAC transgenes encoding fluorescent reporters, Drd2-EGFP (Gong et al., 2003) or Drd1atdTomato (Shuen et al., 2008). These two populations reflect MSNs projecting to the indirect and direct pathways of the basal ganglia, respectively, and have distinct synaptic properties (Kreitzer and Malenka, 2007; Cepeda et al., 2008; Gertler et al., 2008). Using a similar stimulation paradigm, eEPSCs in D2 MSNs from Sapap3 KO mice showed a significant increase in activitydependent depression relative to D2 MSNs from WT mice (eEPSC amplitude relative to baseline, WT, $53 \pm 3 \%, n=13 ; \mathrm{KO}$, $40 \pm 2 \%, n=14 ; p=0.002, t$ test) (Fig. $1 F-H$ ). Paired-pulse ratios of eEPSCs were also significantly increased in D2 MSNs of Sapap3 KO mice relative to WT mice (PPR relative to baseline, $\mathrm{WT}, 113 \pm 2 \%, n=13$; KO, $131 \pm 5 \%, n=14 ; p=0.003, t$ test) (Fig. $1 \mathrm{I}, J$ ). In D1 MSNs, qualitatively similar findings were present in Sapap3 KO mice. However, WT D1 MSNs had a greater degree of activity-dependent depression than WT D2 MSNs in this stimulation paradigm (eEPSC amplitude relative to baseline, D1 WT, $47 \pm 3 \%, n=16$; D2 WT, $53 \pm 3 \%, n=13$ ). As a result, smaller increases in synaptic depression and PPR were observed in D1 MSNs of Sapap3 KO mice compared to WTs (eEPSC amplitude relative to baseline, WT, $47 \pm 3 \%, n=16$; KO, $39 \pm 5 \%$, $n=12 ; p=0.138$, rmANOVA; $p=0.143$, $t$ test; PPR, WT, $118 \pm$ $5 \%, n=16 ; \mathrm{KO}, 129 \pm 5 \%, n=12 ; p=0.02$, rmANOVA; $p=$ $0.117, t$ test). For this reason, in subsequent analyses, we focused on D2 MSNs for whole-cell recording experiments. Together, these experiments show that MSN excitatory synapses of Sapap3 KO mice have increased activity-dependent synaptic depression that is associated with a change in PPR, suggesting a change in release probability.

\section{Excessive synaptic depression at Sapap3 KO excitatory synapses requires endocannabinoid signaling}

It is intriguing to consider that SAPAP3, a postsynaptic protein, may cause enhanced synaptic depression through a presynaptic mechanism. We hypothesized that retrograde signaling by eCBs was involved because abnormalities in eCB signaling could arise from postsynaptic dysfunction and be expressed as a change in presynaptic function. To test this hypothesis, we performed three sets of experiments. First, preincubation of striatal slices with AM251 $(3 \mu \mathrm{M})$, a potent CB1R antagonist, abolished the genotypic differences in activity-dependent depression of both field potential responses (Fig. $2 A-C$ ) and D2 MSN eEPSCs (Fig. 2G-I) between Sapap3 KO and WT mice. Second, we found that the activity-dependent depression was absent at room temperature (PS amplitude relative to baseline, WT, $99 \pm 3 \%, n=6$; KO, $93 \pm$ $6 \%, n=6 ; p=0.391$, $t$ test) (Fig. $2 D$ ). Although temperature may have diverse effects on neurotransmission, these data are consistent with a role for eCBs because, in the striatum, room temperature can inhibit eCB-mediated synaptic depression (Kreitzer and Malenka, 2005; Adermark and Lovinger, 2007; Adermark et al., 2009), presumably due to decreased activity of the plasma membrane transporter required for the extracellular transport of eCBs (Beltramo et al., 1997; Hillard and Jarrahian, 2000; Ronesi et al., 2004; Adermark and Lovinger, 2007; Hillard et al., 2007). Third, genetic deletion of $C B 1 R$ significantly decreased striatal activity-dependent depression and PPR changes in Sapap3 KO mice to levels that were no longer distinguishable from Sapap3 WT mice (PS amplitude relative to baseline, Sapap3 KO/CB1R $\mathrm{KO}, 81 \pm 6 \%, n=11$; WT, $74 \pm 4 \%, n=10 ; p=0.364$; PS PPR relative to baseline, Sapap3 KO/CB1R KO, $120 \pm 4 \%, n=11$; 
$\mathrm{WT}, 124 \pm 3 \%, n=10 ; p=0.357$ ) (Figs. $1 B, D, 2 E, F)$. Thus, together, three lines of evidence show that eCB signaling mediates the excessive depression of MSN excitatory synapses in Sapap3 KO mice.

To investigate whether signaling through CB1Rs was altered in Sapap3 KO MSNs, CB1Rs were directly activated with agonist, WIN 55212-2. At concentrations eliciting submaximal levels of synaptic depression, WIN 55212-2 (1 $\mu \mathrm{M})$ similarly depressed eEPSCs (eEPSC amplitude relative to baseline, WT, $69 \pm 4 \%, n=10$; $\mathrm{KO}, 69 \pm 2 \%, n=14 ; p=0.970, t$ test $)$ (Fig. $2 J$ ) and increased PPR in WT and KO MSNs (PPR relative to baseline, WT, $116 \pm 3 \%, n=10 ; \mathrm{KO}, 120 \pm 6 \%, n=14$; $p=0.559, t$ test $)$. Therefore, although CB1Rs are required for the activitydependent depression, we found no evidence for an alteration in CB1R signaling itself in Sapap3 KO mice.

\section{Sapap3 KO MSNs engage \\ endocannabinoid signaling under anomalous conditions}

When eCB signaling is blocked, a degree of synaptic depression persists in both genotypes (Fig. $2 B, E, H$ ). Therefore, we investigated the degree of synaptic depression that is mediated by eCBs in each genotype by comparing depression in the absence and presence of AM251 within genotypes. At WT striatal excitatory synapses, AM251 does not alter the degree of eEPSC depression (Fig. $2 \mathrm{~K}$ ), indicating that eCB-mediated synaptic depression is not normally engaged under these conditions. By contrast, an AM251-sensitive component of synaptic depression was readily observed at striatal excitatory synapses lacking SAPAP3 (Fig. $2 \mathrm{~L}$ ). Furthermore, the eCB-independent component of depression is similar in KO and WT MSNs (Fig. 1,2). These findings reveal that loss of SAPAP3 engages eCB-mediated synaptic plasticity when it is not normally expressed.

\section{Anomalous endocannabinoid synaptic plasticity at Sapap3 KO synapses requires mGluR5 activity}

Because we observed eCB-mediated synaptic plasticity under anomalous conditions in Sapap3 KO mice, we evaluated whether the upstream signaling events that are normally required for $\mathrm{eCB}$ activity at striatal excitatory synapses were also required in this aberrant context. Endocannabinoid-mediated LTD is a welldescribed form of eCB-mediated synaptic plasticity at striatal MSN excitatory synapses. Striatal eCB-LTD requires both L-type voltage gated calcium channels and group $1 \mathrm{mGluRs}$ (Calabresi et al., 1994; Sung et al., 2001; Kreitzer and Malenka, 2005; Wang et al., 2006). Short-term eCB-mediated synaptic plasticity as a result of afferent axonal stimulation alone has not been described at these synapses. However, these synapses do appear to be capable of short-term eCB-mediated synaptic plasticity if G-protein coupled receptors (GPCRs) critical for triggering endocannabinoid release, such as group $1 \mathrm{mGluRs}$, are pharmacologically stimu- lated (Kreitzer and Malenka, 2005; Narushima et al., 2006; Yin and Lovinger, 2006).

In Sapap3 KO MSNs, the mGluR5 antagonist, MPEP (40 $\mu \mathrm{M})$, significantly reduced the degree of activity-dependent synaptic depression and PPR increase (Fig. $3 A, B$ ). Levels of activitydependent synaptic depression and PPR in MPEP-treated Sapap3 $\mathrm{KO}$ mice were indistinguishable from WT mice (Fig. $3 C, D$ ). By contrast, the L-type calcium channel antagonist, nifedipine (10 $\mu \mathrm{M})$, had no effect on synaptic depression or PPR at Sapap3 KO D2 MSNs (Fig. $3 E, F$ ). These results indicate that the anomalous eCB-mediated plasticity of Sapap3 KO striatal excitatory synapses requires signaling by mGluR5.

Group $1 \mathrm{mGluR}$ signaling and mGluR5 surface expression are increased in MSNs of Sapap3 KO mice

Because mGluR5 activity is required for the abnormal synaptic depression in Sapap3 KO mice, and SAPAP3 might alter group 1 mGluR activity by virtue of its biochemical interaction with Shank, a protein found in a complex with group 1 mGluRs (Tu et al., 1999; Sala et al., 2001; Hwang et al., 2005), we investigated whether Sapap3 deletion altered the activity of group I mGluRs. Activity of these receptors was monitored by measuring changes in intracellular calcium levels in response to application of DHPG, a nonselective group $1 \mathrm{mGluR}$ agonist. Group $1 \mathrm{mGluRs}$ 
A
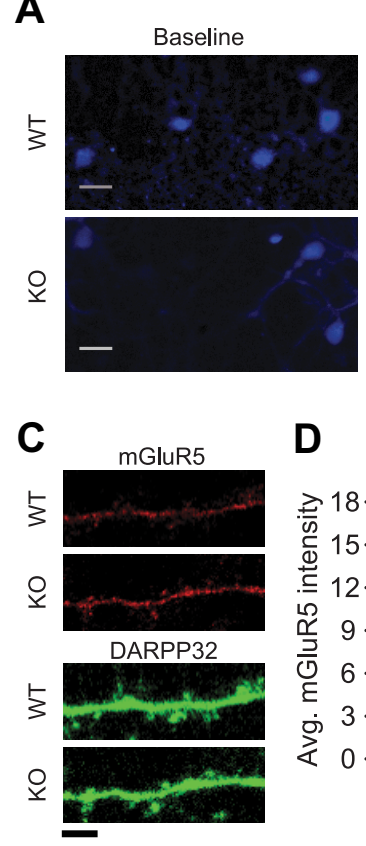

B

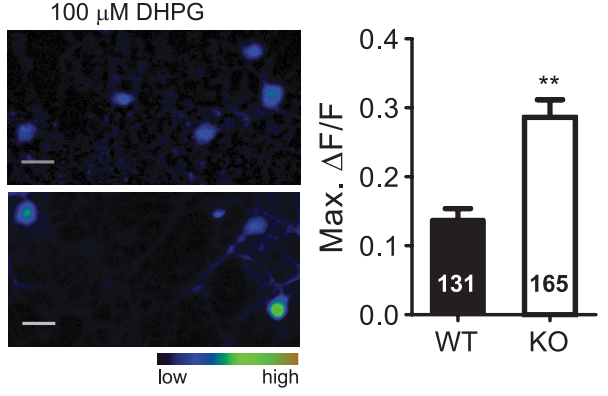

E

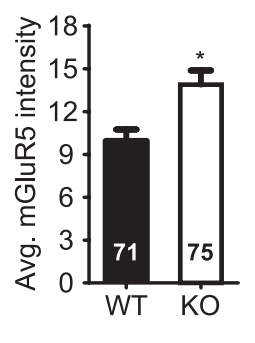

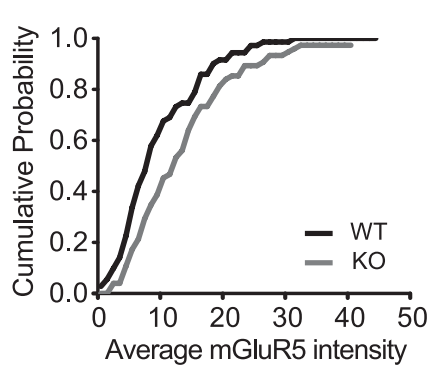

Figure 5. Intracellular calcium transients in response to group $1 \mathrm{mGluR}$ activation and surface expression of mGluR5 are increased in Sapap3 K0 striatal neurons from corticostriatal cocultures. $A$, Pseudocolored images of Fluo-4 intensity in corticostriatal cocultured neurons from Sapap 3 WT (top) and K0 mice (bottom). Sample images correspond to baseline period and $5 \mathrm{~s}$ after 100 $\mu \mathrm{M}$ DHPG application. $\boldsymbol{B}$, Bar graph of the peak Fluo-4 response in the $10 \mathrm{~s}$ period following DHPG application demonstrates increased calcium transients in MSNs from Sapap3 KO cultures ( $n=131$ cells, 12 wells, 3 culture preparations) relative to WT cultures ( $n=165$ cells, 13 wells, 3 culture preparations; $p<0.0001$, Mann-Whitney test). C, Example images of mGluR5 surface immunostaining on DARPP-32-positive dendritic regions in corticostriatal cocultures from Sapap3 WT and K0 mice (top). DARPP-32 staining (pseudocolored in green) was used to identify medium spiny neurons (bottom). $\boldsymbol{D}$, The average mGluR5 intensity is significantly higher in Sapap3 KO cultures compared to WT mice ( $p=0.003$; Mann-Whitney test). $\boldsymbol{E}$, Cumulative probability plot shows a rightward shift across all intensities of mGluR5 surface staining of dendritic regions from Sapap $3 \mathrm{KO}$ mice compared to WT mice. Scale bars: $\boldsymbol{A}, 10 \mu \mathrm{m} ; \boldsymbol{C}, 5 \mu \mathrm{m} .{ }^{*} p<0.05 ;{ }^{* *} p<0.01$.

are coupled to $\mathrm{G} \alpha_{\mathrm{q} / 11}$-type $\mathrm{G}$-proteins that increase cytosolic calcium when activated as a consequence of phospholipase $\mathrm{C}$ activation and inositol-1,4,5-trisphosphate production. In this assay, DHPG $(100 \mu \mathrm{M})$ was applied to acute striatal brain slices expressing fluorescent reporters to differentiate D1 and D2 MSNs and in the presence of tetrodotoxin to prevent action potentials. Intracellular calcium levels were monitored in the somata of striatal MSNs using the calcium indicator dye, fura-2 AM and twophoton microscopic imaging. In response to DHPG, both D1 and D2 MSNs from Sapap3 KO mice had larger calcium transients compared to WT MSNs (Fig. 4).

We next investigated whether surface levels of group 1 mGluRs were also altered by Sapap3 deletion. Immunocytochemical methods were used to measure mGluR5 surface levels on dendrites of striatal neurons (indicated by highintensity DARPP-32 immunostaining) in corticostriatal cocultures. We first confirmed that the cultured striatal neurons from Sapap3 KO mice faithfully reproduced the intracellular calcium signaling abnormality in response to DHPG that was observed in acute brain slice MSNs (Fig. 5A, B). Using this culture preparation, the average mGluR 5 immunostaining intensity for a given dendritic region was measured. The average intensity of mGluR5 immunostaining on DARPP-32-positive dendrites was significantly increased in Sapap3 KO neurons as compared to WT (WT, $10 \pm 0.8$ a.u. per pixel, $n=71$ dendritic regions; KO, $14 \pm 1$ a.u. per pixel, $n=75$ dendritic regions; $p=0.003$, MannWhitney test) (Fig. 5C,D). Analysis of the distribution of average mGluR5 intensities over the population of dendrites examined in each group further revealed that a uniform rightward shift was responsible for this increase, rather than a discrete change in a subpopulation of dendrites (Fig. 5E).

Enhancing synaptic mGluR5 activity at WT synapses increases activity-dependent depression

Thus far, our results suggest that an increase in the number and/or activity of type 5 mGluRs may underlie the enhanced eCB-mediated synaptic plasticity observed at MSN excitatory synapses of Sapap3 KO mice. To directly test this possibility, we examined the role of mGluR5 activation in this process. If increased activation of mGluR5 was responsible for triggering eCB-mediated synaptic depression in Sapap3 KO mice, increasing the number of activated type $5 \mathrm{mGluRs}$ at WT synapses might be sufficient to reproduce the KO phenotype. Likewise, the same manipulation might be occluded at $\mathrm{KO}$ synapses.

To selectively increase the activity of only those mGluRs that are endogenously exposed to glutamate upon synaptic stimulation, the positive allosteric modulator of mGluR5, CDPPB was used (Lindsley et al., 2004; Kinney et al., 2005). In the activity-dependent stimulation paradigm, potentiation of synaptically activated mGluR5 by CDPPB increased the level of WT synaptic depression to that of $\mathrm{KO}$ synapses [WT + CDPPB, $55 \pm 8 \%, n=8$; $\mathrm{KO}+\mathrm{CDPPB}, 53 \pm 5 \%, n=10 ; p=0.836, t$ test; $\mathrm{WT}+\mathrm{CDPPB}$ (Fig. 6B) vs $\mathrm{KO}$ (Fig. 1C); $p=0.328, t$ test] (Fig. 6A,B). By contrast, at KO synapses, $\mathrm{CDPPB}$ did not increase depression $[\mathrm{KO}+\mathrm{CDPPB}$ (Fig. $6 B$ ) vs $\mathrm{KO}$ (Fig. $1 C$ ); $p=0.350, t$ test $]$. Similar effects on field PS PPR were observed (Fig. 6C,D).

These results demonstrate that in WT mice, enhanced mGluR5 activation is sufficient to reproduce the degree of activity-dependent depression observed in $\mathrm{KO}$ mice. In addition, KO synapses do not express further activity-dependent depression with $\mathrm{CDPPB}$, suggesting that the anomalous depression in $\mathrm{KO}$ synapses is due to enhanced mGluR5 activity.

\section{Anomalous endocannabinoid signaling at Sapap3 KO striatal} excitatory synapses produces short-term eCB plasticity

To investigate whether the $90 \mathrm{~s} / 10 \mathrm{~s}$ interval activity-dependent depression protocol resulted in short- or long-lasting synaptic depression of KO synapses, we performed two experiments. First, after 20 min of paired stimulation at $10 \mathrm{~s}$ intervals, AM251 was capable of reversing the depression and PPR changes of Sapap3 KO synapses to levels indistinguishable from WT (Fig. 7A,B). Second, when electrical stimulation was paused briefly (10 min) and resumed at the reduced rate of each $90 \mathrm{~s}$ interval, synaptic responses returned to basal values ( $100 \pm 7 \%$ of baseline; $n=5$; $p=0.963, t$ test compared with initial baseline) (Fig. $7 C$ ). These two experimental paradigms indicate that the anomalous eCBmediated synaptic plasticity observed in Sapap3 KO synapses is a form of short-term plasticity. Short-term eCB-mediated synaptic plasticity in the absence of pharmacological stimulation of 

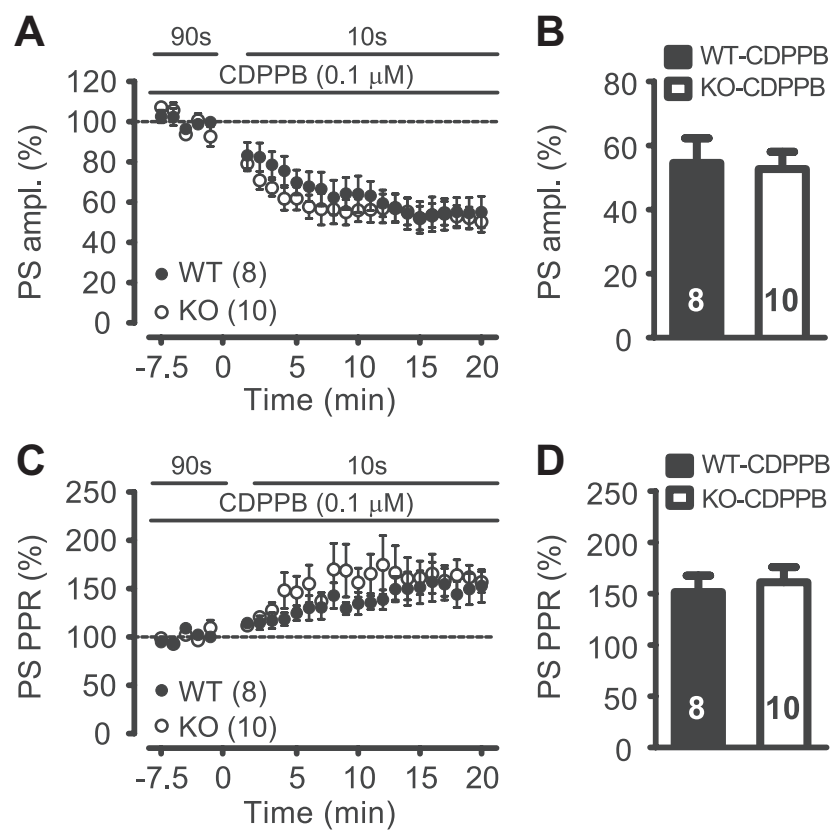

Figure 6. Augmentation of mGluR5 activity by the positive allosteric mGluR5 modulator, CDPPB, during the activity-dependent protocol increases depression of WT responses to KO levels. $\boldsymbol{A}, \boldsymbol{B}$, In the presence of CDPPB $(0.1 \mu \mathrm{M})$, the activity-dependent protocol depresses dorsolateral striatal PS field responses of WT and KO mice similarly. Summary bar graphs show the average response during the last $10 \mathrm{~min}$ of $10 \mathrm{~s}$ stimulation interval period relative to baseline ( $p=0.541$, rmANOVA; $p=0.836, t$ test). $C, D$, In the presence of $\operatorname{CDPPB}(0.1 \mu \mathrm{m})$, the activity-dependent protocol increases PS PPR similarly in WT and K0 mice ( $p=0.816$, rmANOVA; $p=0.664, t$ test).
GPCRs has not been reported at these synapses. Thus, Sapap3 deletion alters the conditions required for engaging eCBmediated synaptic depression.

To test whether Sapap3 deletion alters the magnitude of eCBmediated synaptic depression, we induced eCB LTD, a readily observed form of eCB synaptic plasticity at D2 MSN excitatory synapses. Endocannabinoid LTD was induced by a commonly used protocol, delivering four high-frequency stimulation trains paired with postsynaptic depolarization (Choi and Lovinger, 1997; Kreitzer and Malenka, 2005; Wang et al., 2006). No differences in the magnitude of LTD were observed between genotypes (eEPSC amplitude relative to baseline, WT, $54 \pm 7 \%, n=6$; $\mathrm{KO}$, $57 \pm 6 \%, n=6 ; p=0.723, t$ test) (Fig. 7D). Thus, although Sapap3 deletion alters the conditions for engaging eCB-mediated synaptic depression, we did not find evidence that Sapap3 deletion alters the magnitude of such depression once engaged (Fig. $6 A, B, 7 D)$.

\section{Discussion}

In the brain, mGluR-dependent endocannabinoid signaling is a common mechanism for activity-dependent regulation of synaptic strength. Although the pathway stimulating the synthesis of endocannabinoids has been well studied (Kano et al., 2009), little is known about postsynaptic mechanisms regulating the induction of this pathway. Here, we investigate excitatory synaptic transmission of striatal MSNs in Sapap3 KO mice and identify a role for SAPAPs in regulating the induction of eCB-mediated synaptic plasticity. Our results indicate that the normal role of SAPAPs is to negatively regulate mGluR5 activity and thereby restrict the conditions under which eCB-mediated synaptic de-
A

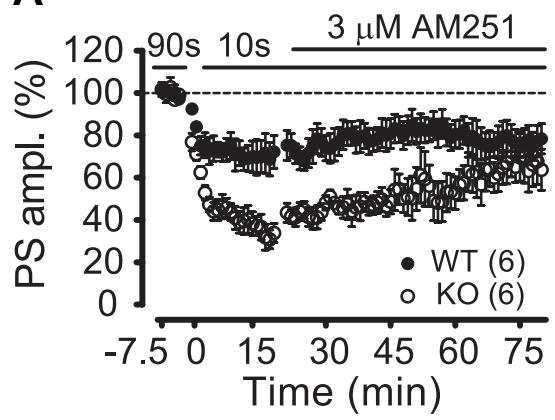

C

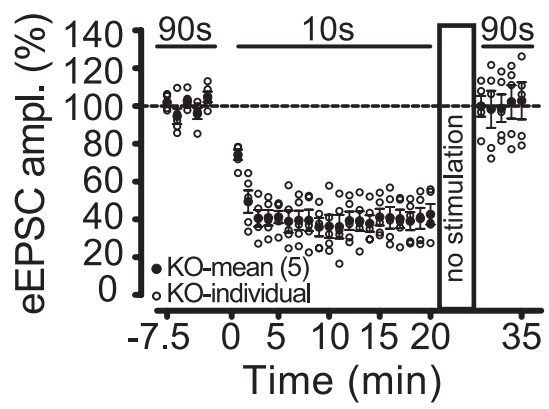

B
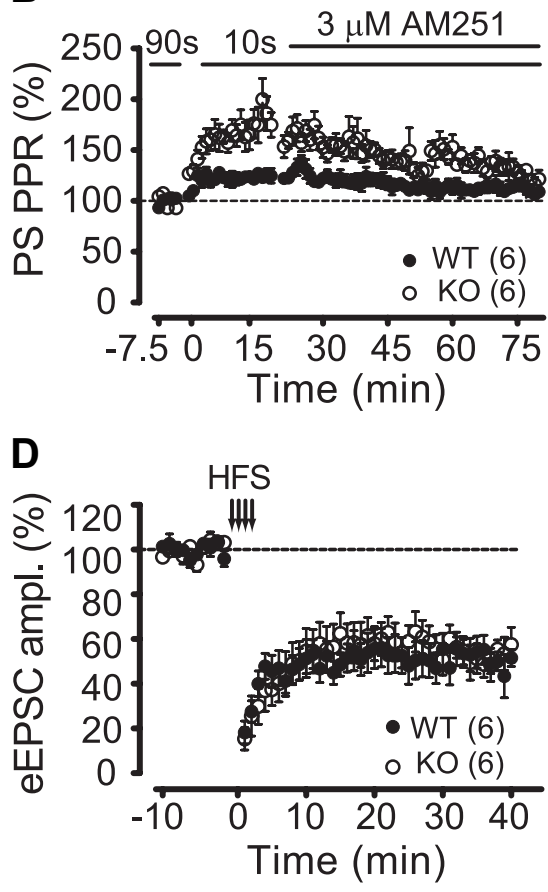

E

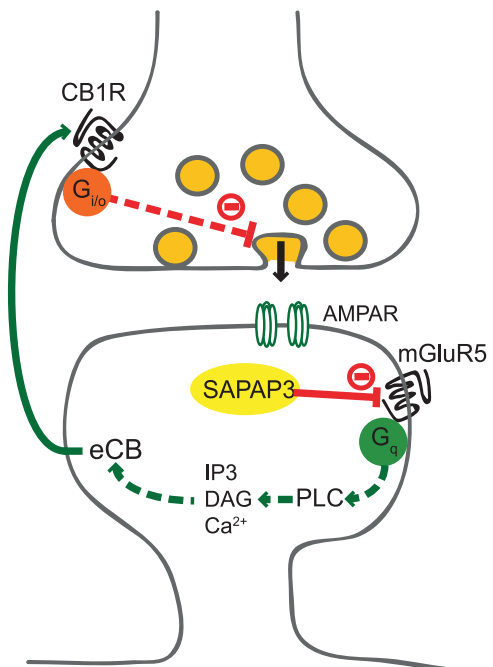

Figure 7. Sapap3 deletion induces short-term eCB-mediated plasticity, but does not alter magnitude of long-term eCB-mediated plasticity. $\boldsymbol{A}, \boldsymbol{B}$, In field recordings, AM251 applied after steady-state responses achieved at the $10 \mathrm{~s}$ stimulation interval reverses the PS depression $(\boldsymbol{A})$ and paired-pulse ratio changes (B) of striatal excitatory synapses in Sapap3 K0 to levels indistinguishable from WT mice. Bars indicate periods of stimulation interval and drug application. C, Pausing stimulation for 10 min is sufficient to return D2 MSN eEPSCs to basal values when stimulation is resumed at a lower rate ( 90 s interval, $50 \mathrm{~ms}$ IPI paired pulses). D. There is no difference in the magnitude of LTD elicited between WT and K0 D2 MSN eEPSCS $(p=0.616 ;$ rmANOVA). Arrows indicate time of LTD induction by HFS ( 4 trains of $100 \mathrm{~Hz}$ stimulation paired with 0 mV depolarization). $\boldsymbol{E}$, Working model depicts SAPAP3 negatively regulating surface levels and activity of mGluR5. In the absence of SAPAP3, increased activity of mGluR5 leads to increased endocannabinoid signaling and inhibition of presynaptic neurotransmitter release. 
pression occurs (Fig. 7E). These results identify SAPAPs for the first-time as potential mediators of endocannabinoid metaplasticity and further suggest that altered mGluR and/or eCB signaling may contribute to the pathological OCD-like behaviors of Sapap3 mutant mice.

\section{Loss of SAPAP3 promotes eCB-mediated synaptic plasticity at MSN excitatory synapses}

Endocannabinoids mediate diverse forms of synaptic plasticity throughout the nervous system. Conditions for the induction and expression of eCB-mediated synaptic plasticity can vary among circuits and between activity states (for review, see Wilson and Nicoll, 2002; Heifets and Castillo, 2009; Kano et al., 2009; Lovinger, 2010). Presynaptic factors have been identified that can influence whether short- or long-term inhibition of presynaptic release occurs as a consequence of CB1R activation (Ronesi et al., 2004; Chevaleyre et al., 2007; Singla et al., 2007). Although there is also evidence that postsynaptic mechanisms are at play, little is known about specific postsynaptic molecules that regulate eCB-mediated synaptic plasticity (Edwards et al., 2008; Kim and Alger, 2010; Roloff et al., 2010). In the present study, we observe that excitatory striatal synapses of Sapap3 KO mice engage eCB signaling under conditions that are not normally sufficient to elicit eCB-mediated synaptic depression. Although both genotypes exhibit synaptic depression under the activity-dependent protocol, only Sapap3 KO mice express an eCB-dependent component. Our results further provide evidence that (1) there is a threshold level of mGluR activation that is required to trigger eCB-mediated synaptic depression, (2) KO synapses reach threshold under conditions that WT synapses do not, and (3) once eCBmediated synaptic depression is triggered, there are not additional significant differences in the magnitude of the effect at KO synapses in comparison to WT synapses. These results indicate that SAPAP3 may primarily influence the context under which eCB-mediated synaptic depression is activated. In this study, we show that genetic deletion of Sapap3 lowers the threshold for activating eCB-mediated synaptic plasticity by increasing mGluR activity. In future studies, it will be of interest to determine how SAPAP3 activity is modulated in space and time to regulate mGluR activity and eCB-mediated synaptic plasticity.

\section{Loss of SAPAP 3 increases group $1 \mathrm{mGluR}$ activity and mGluR5 cell surface expression}

Group 1 mGluRs are known triggers for eCB synthesis (Maejima et al., 2001; Varma et al., 2001; Ohno-Shosaku et al., 2002). In Sapap3 KO neurons, we observe both a functional increase in group 1 mGluR activity (intracellular calcium transients in response to DHPG) and a physical increase in mGluR5 surface receptors. These findings provide a mechanism for increased eCB-mediated synaptic plasticity at Sapap3 $\mathrm{KO}$ synapses. Although it is logical to speculate that the increased surface receptors are responsible for the increased mGluR activity, our data do not exclude the possibility that mGluR activation or coupling to downstream signaling events is enhanced independent of the increase in surface receptors. Such changes in group $1 \mathrm{mGluR}$ activity have been reported when mGluR scaffolding is altered (Ango et al., 2001; Sala et al., 2005; Kammermeier and Worley, 2007). Likewise, although most of the experiments specifically evaluate mGluR5, the predominant group $1 \mathrm{mGluR}$ expressed in MSNs, we cannot exclude the possibility that Sapap 3 deletion also increases
mGluR1 activity. Our findings of enhanced group $1 \mathrm{mGluR}$ activity in Sapap3 KO mice indicate that other downstream sequelae of group 1 mGluR activation may also be altered.

One potential mechanism for the increase in surface mGluR5 in Sapap3 KO mice is through an impairment of mGluR endocytosis. This possibility is supported by prior studies that implicate Homer proteins in receptor endocytosis and localization of endocytic zones to dendritic spines (Gray et al., 2003; Davidkova and Carroll, 2007; Lu et al., 2007; Petrini et al., 2009). Homer proteins form a ternary complex with SAPAP3 and Shank3, providing a biochemical basis by which loss of SAPAP 3 could alter Homer activity (Tu et al., 1999; Sala et al., 2001). A specific role for Homer in regulating group $1 \mathrm{mGluR}$ endocytosis and surface levels has been demonstrated in experiments over-expressing Homer 1a, a short form of Homer that disrupts the interaction of long forms of Homer proteins with other scaffold proteins (Minami et al., 2003). Several recent studies demonstrate that Homer proteins can also alter group $1 \mathrm{mGluR}$-dependent endocannabinoid signaling (Fourgeaud et al., 2004; Jung et al., 2007; Roloff et al., 2010). Together these findings suggest that Shank and Homer may be functionally important in mediating the effects of SAPAP3 on group 1 mGluRs and endocannabinoids. Further experiments directly testing the role of these protein interactions are necessary.

Intriguingly, two clinical disorders that share a core feature of compulsive-repetitive behaviors, autism and Fragile X mental retardation, might also disrupt signaling through a putative mGluR/Homer/Shank/SAPAP pathway. Shank3 mutation is associated with a form of autism (Durand et al., 2007). Shank proteins interact biochemically with SAPAP and Homer (Tu et al., 1999). In mouse models for Fragile X mental retardation, SAPAP3 levels are altered (Narayanan et al., 2008), and both excessive group $1 \mathrm{mGluR}$ and endocannabinoid activity have been reported (Huber et al., 2002; Bear et al., 2004; Maccarrone et al., 2010; Zhang and Alger, 2010). These behavioral and molecular similarities with Sapap3 KO mice suggest that increased mGluR5 activity and/or eCB-mediated synaptic plasticity in the striatum may represent a common mechanism for the expression of compulsive-repetitive behaviors.

\section{References}

Adermark L, Lovinger DM (2007) Retrograde endocannabinoid signaling at striatal synapses requires a regulated postsynaptic release step. Proc Natl Acad Sci U S A 104:20564-20569.

Adermark L, Talani G, Lovinger DM (2009) Endocannabinoid-dependent plasticity at GABAergic and glutamatergic synapses in the striatum is regulated by synaptic activity. Eur J Neurosci 29:32-41.

Ango F, Prezeau L, Muller T, Tu JC, Xiao B, Worley PF, Pin JP, Bockaert J, Fagni L (2001) Agonist-independent activation of metabotropic glutamate receptors by the intracellular protein Homer. Nature 411:962-965.

Bear MF, Huber KM, Warren ST (2004) The mGluR theory of fragile X mental retardation. Trends Neurosci 27:370-377.

Beltramo M, Stella N, Calignano A, Lin SY, Makriyannis A, Piomelli D (1997) Functional role of high-affinity anandamide transport, as revealed by selective inhibition. Science 277:1094-1097.

Boeckers TM, Winter C, Smalla KH, Kreutz MR, Bockmann J, Seidenbecher C, Garner CC, Gundelfinger ED (1999) Proline-rich synapse-associated proteins ProSAP1 and ProSAP2 interact with synaptic proteins of the SAPAP/GKAP family. Biochem Biophys Res Commun 264:247-252.

Calabresi P, Pisani A, Mercuri NB, Bernardi G (1994) Post-receptor mechanisms underlying striatal long-term depression. J Neurosci 14:4871-4881.

Cepeda C, Andre VM, Yamazaki I, Wu N, Kleiman-Weiner M, Levine MS (2008) Differential electrophysiological properties of dopamine D1 and D2 receptor-containing striatal medium-sized spiny neurons. Eur J Neurosci 27:671-682. 
Chevaleyre V, Heifets BD, Kaeser PS, Sudhof TC, Purpura DP, Castillo PE (2007) Endocannabinoid-Mediated Long-Term Plasticity Requires cAMP/PKA Signaling and RIM1alpha. Neuron 54:801-812.

Choi S, Lovinger DM (1997) Decreased probability of neurotransmitter release underlies striatal long-term depression and postnatal development of corticostriatal synapses. Proc Natl Acad Sci U S A 94:2665-2670.

Davidkova G, Carroll RC (2007) Characterization of the role of microtubule-associated protein $1 \mathrm{~B}$ in metabotropic glutamate receptormediated endocytosis of AMPA receptors in hippocampus. J Neurosci 27:13273-13278.

Durand CM, Betancur C, Boeckers TM, Bockmann J, Chaste P, Fauchereau F, Nygren G, Rastam M, Gillberg IC, Anckarsäter H, Sponheim E, GoubranBotros H, Delorme R, Chabane N, Mouren-Simeoni MC, de Mas P, Bieth E, Rogé B, Héron D, Burglen L, et al (2007) Mutations in the gene encoding the synaptic scaffolding protein SHANK3 are associated with autism spectrum disorders. Nat Genet 39:25-27.

Edwards DA, Zhang L, Alger BE (2008) Metaplastic control of the endocannabinoid system at inhibitory synapses in hippocampus. Proc Natl Acad Sci U S A 105:8142-8147.

Fourgeaud L, Mato S, Bouchet D, Hemar A, Worley PF, Manzoni OJ (2004) A single in vivo exposure to cocaine abolishes endocannabinoid-mediated long-term depression in the nucleus accumbens. J Neurosci 24:6939-6945.

Gertler TS, Chan CS, Surmeier DJ (2008) Dichotomous anatomical properties of adult striatal medium spiny neurons. J Neurosci 28:10814-10824.

Gong S, Zheng C, Doughty ML, Losos K, Didkovsky N, Schambra UB, Nowak NJ, Joyner A, Leblanc G, Hatten ME, Heintz N (2003) A gene expression atlas of the central nervous system based on bacterial artificial chromosomes. Nature 425:917-925.

Gray NW, Fourgeaud L, Huang B, Chen J, Cao H, Oswald BJ, Hemar A, McNiven MA (2003) Dynamin 3 is a component of the postsynapse, where it interacts with mGluR5 and Homer. Curr Biol 13:510-515.

Heifets BD, Castillo PE (2009) Endocannabinoid signaling and long-term synaptic plasticity. Annu Rev Physiol 71:283-306.

Hillard CJ, Jarrahian A (2000) The movement of N-arachidonoylethanolamine (anandamide) across cellular membranes. Chem Phys Lipids 108:123-134.

Hillard CJ, Shi L, Tuniki VR, Falck JR, Campbell WB (2007) Studies of anandamide accumulation inhibitors in cerebellar granule neurons: comparison to inhibition of fatty acid amide hydrolase. J Mol Neurosci 33:18-24.

Hirao K, Hata Y, Deguchi M, Yao I, Ogura M, Rokukawa C, Kawabe H, Mizoguchi A, Takai Y (2000) Association of synapse-associated protein 90/ postsynaptic density-95-associated protein (SAPAP) with neurofilaments. Genes Cells 5:203-210.

Huber KM, Gallagher SM, Warren ST, Bear MF (2002) Altered synaptic plasticity in a mouse model of fragile X mental retardation. Proc Natl Acad Sci U S A 99:7746-7750.

Hwang JI, Kim HS, Lee JR, Kim E, Ryu SH, Suh PG (2005) The interaction of phospholipase C-beta3 with Shank2 regulates mGluR-mediated calcium signal. J Biol Chem 280:12467-12473.

Jung KM, Astarita G, Zhu C, Wallace M, Mackie K, Piomelli D (2007) A key role for diacylglycerol lipase-alpha in metabotropic glutamate receptor-dependent endocannabinoid mobilization. Mol Pharmacol 72:612-621.

Kammermeier PJ, Worley PF (2007) Homer la uncouples metabotropic glutamate receptor 5 from postsynaptic effectors. Proc Natl Acad Sci U S A 104:6055-6060.

Kano M, Ohno-Shosaku T, Hashimotodani Y, Uchigashima M, Watanabe M (2009) Endocannabinoid-mediated control of synaptic transmission. Physiol Rev 89:309-380.

Kim E, Sheng M (2004) PDZ domain proteins of synapses. Nat Rev Neurosci 5:771-781.

Kim E, Naisbitt S, Hsueh YP, Rao A, Rothschild A, Craig AM, Sheng M (1997) GKAP, a novel synaptic protein that interacts with the guanylate kinase-like domain of the PSD-95/SAP90 family of channel clustering molecules. J Cell Biol 136:669-678.

Kim J, Alger BE (2010) Reduction in endocannabinoid tone is a homeostatic mechanism for specific inhibitory synapses. Nat Neurosci 13:592-600.

Kindler S, Rehbein M, Classen B, Richter D, Bockers TM (2004) Distinct spatiotemporal expression of SAPAP transcripts in the developing rat brain: a novel dendritically localized mRNA. Brain Res Mol Brain Res 126:14-21.

Kinney GG, O’Brien JA, Lemaire W, Burno M, Bickel DJ, Clements MK, Chen TB, Wisnoski DD, Lindsley CW, Tiller PR, Smith S, Jacobson MA, Sur C, Duggan ME, Pettibone DJ, Conn PJ, Williams DL Jr (2005) A novel selective positive allosteric modulator of metabotropic glutamate receptor subtype 5 has in vivo activity and antipsychotic-like effects in rat behavioral models. J Pharmacol Exp Ther 313:199-206.

Kreitzer AC, Malenka RC (2005) Dopamine modulation of state-dependent endocannabinoid release and long-term depression in the striatum. J Neurosci 25:10537-10545.

Kreitzer AC, Malenka RC (2007) Endocannabinoid-mediated rescue of striatal LTD and motor deficits in Parkinson's disease models. Nature 445:643-647.

Lindsley CW, Wisnoski DD, Leister WH, O’Brien JA, Lemaire W, Williams DL Jr, Burno M, Sur C, Kinney GG, Pettibone DJ, Tiller PR, Smith S, Duggan ME, Hartman GD, Conn PJ, Huff JR (2004) Discovery of positive allosteric modulators for the metabotropic glutamate receptor subtype 5 from a series of $\mathrm{N}$-(1,3-diphenyl-1H- pyrazol-5yl)benzamides that potentiate receptor function in vivo. J Med Chem 47:5825-5828.

Lovinger DM (2010) Neurotransmitter roles in synaptic modulation, plasticity and learning in the dorsal striatum. Neuropharmacology 58:951-961.

Lovinger DM, McCool BA (1995) Metabotropic glutamate receptormediated presynaptic depression at corticostriatal synapses involves mGLuR2 or 3. J Neurophysiol 73:1076-1083.

Lu J, Helton TD, Blanpied TA, Racz B, Newpher TM, Weinberg RJ, Ehlers MD (2007) Postsynaptic positioning of endocytic zones and AMPA receptor cycling by physical coupling of dynamin-3 to Homer. Neuron 55:874-889.

Maccarrone M, Rossi S, Bari M, De Chiara V, Rapino C, Musella A, Bernardi G, Bagni C, Centonze D (2010) Abnormal mGlu 5 receptor/endocannabinoid coupling in mice lacking FMRP and BC1 RNA. Neuropsychopharmacology 35:1500-1509.

MacLean JN, Yuste R (2009) Imaging action potentials with calcium indicators. Cold Spring Harb Protoc 2009; doi:10.1101/pdb.prot5316.

Maejima T, Hashimoto K, Yoshida T, Aiba A, Kano M (2001) Presynaptic inhibition caused by retrograde signal from metabotropic glutamate to cannabinoid receptors. Neuron 31:463-475.

Minami I, Kengaku M, Smitt PS, Shigemoto R, Hirano T (2003) Long-term potentiation of mGluR1 activity by depolarization-induced Homerla in mouse cerebellar Purkinje neurons. Eur J Neurosci 17:1023-1032.

Naisbitt S, Kim E, Weinberg RJ, Rao A, Yang FC, Craig AM, Sheng M (1997) Characterization of guanylate kinase-associated protein, a postsynaptic density protein at excitatory synapses that interacts directly with postsynaptic density-95/synapse-associated protein 90 . J Neurosci 17:5687-5696.

Narayanan U, Nalavadi V, Nakamoto M, Thomas G, Ceman S, Bassell GJ, Warren ST (2008) S6K1 phosphorylates and regulates fragile X mental retardation protein (FMRP) with the neuronal protein synthesisdependent mammalian target of rapamycin (mTOR) signaling cascade. J Biol Chem 283:18478-18482.

Narushima M, Hashimoto K, Kano M (2006) Endocannabinoid-mediated short-term suppression of excitatory synaptic transmission to medium spiny neurons in the striatum. Neurosci Res 54:159-164.

Nikolenko V, Watson BO, Araya R, Woodruff A, Peterka DS, Yuste R (2008) SLM microscopy: scanless two-photon imaging and photostimulation with spatial light modulators. Front Neural Circuits 2:5.

Ohno-Shosaku T, Shosaku J, Tsubokawa H, Kano M (2002) Cooperative endocannabinoid production by neuronal depolarization and group I metabotropic glutamate receptor activation. Eur J Neurosci 15:953-961.

Petrini EM, Lu J, Cognet L, Lounis B, Ehlers MD, Choquet D (2009) Endocytic trafficking and recycling maintain a pool of mobile surface AMPA receptors required for synaptic potentiation. Neuron 63:92-105.

Roloff AM, Anderson GR, Martemyanov KA, Thayer SA (2010) Homer la gates the induction mechanism for endocannabinoid-mediated synaptic plasticity. J Neurosci 30:3072-3081.

Romorini S, Piccoli G, Jiang M, Grossano P, Tonna N, Passafaro M, Zhang M, Sala C (2004) A functional role of postsynaptic density-95-guanylate 
kinase-associated protein complex in regulating Shank assembly and stability to synapses. J Neurosci 24:9391-9404.

Ronesi J, Gerdeman GL, Lovinger DM (2004) Disruption of endocannabinoid release and striatal long-term depression by postsynaptic blockade of endocannabinoid membrane transport. J Neurosci 24:1673-1679.

Rumbaugh G, Sia GM, Garner CC, Huganir RL (2003) Synapse-associated protein-97 isoform-specific regulation of surface AMPA receptors and synaptic function in cultured neurons. J Neurosci 23:4567-4576.

Sala C, Piech V, Wilson NR, Passafaro M, Liu GS, Sheng M (2001) Regulation of dendritic spine morphology and synaptic function by Shank and Homer. Neuron 31:115-130.

Sala C, Roussignol G, Meldolesi J, Fagni L (2005) Key role of the postsynaptic density scaffold proteins shank and homer in the functional architecture of $\mathrm{Ca} 2+$ homeostasis at dendritic spines in hippocampal neurons. J Neurosci 25:4587-4592.

Sheng M, Pak DT (1999) Glutamate receptor anchoring proteins and the molecular organization of excitatory synapses. Ann N Y Acad Sci 868:483-493.

Shuen JA, Chen M, Gloss B, Calakos N (2008) Drd1a-tdTomato BAC transgenic mice for simultaneous visualization of medium spiny neurons in the direct and indirect pathways of the basal ganglia. J Neurosci 28:2681-2685.

Singla S, Kreitzer AC, Malenka RC (2007) Mechanisms for synapse specificity during striatal long-term depression. J Neurosci 27:5260-5264.

Sung KW, Choi S, Lovinger DM (2001) Activation of group I mGluRs is necessary for induction of long-term depression at striatal synapses. J Neurophysiol 86:2405-2412.

Takeuchi M, Hata Y, Hirao K, Toyoda A, Irie M, Takai Y (1997) SAPAPs. A family of PSD-95/SAP90-associated proteins localized at postsynaptic density. J Biol Chem 272:11943-11951.

Tu JC, Xiao B, Naisbitt S, Yuan JP, Petralia RS, Brakeman P, Doan A, Aakalu VK, Lanahan AA, Sheng M, Worley PF (1999) Coupling of mGluR/
Homer and PSD-95 complexes by the Shank family of postsynaptic density proteins. Neuron 23:583-592.

Valtschanoff JG, Weinberg RJ (2001) Laminar organization of the NMDA receptor complex within the postsynaptic density. J Neurosci 21:1211-1217.

Varma N, Carlson GC, Ledent C, Alger BE (2001) Metabotropic glutamate receptors drive the endocannabinoid system in hippocampus. J Neurosci 21:RC188.

Wang Z, Kai L, Day M, Ronesi J, Yin HH, Ding J, Tkatch T, Lovinger DM, Surmeier DJ (2006) Dopaminergic control of corticostriatal long-term synaptic depression in medium spiny neurons is mediated by cholinergic interneurons. Neuron 50:443-452.

Welch JM, Wang D, Feng G (2004) Differential mRNA expression and protein localization of the SAP90/PSD-95-associated proteins (SAPAPs) in the nervous system of the mouse. J Comp Neurol 472:24-39.

Welch JM, Lu J, Rodriguiz RM, Trotta NC, Peca J, Ding JD, Feliciano C, Chen M, Adams JP, Luo J, Dudek SM, Weinberg RJ, Calakos N, Wetsel WC, Feng G (2007) Cortico-striatal synaptic defects and OCD-like behaviours in Sapap3-mutant mice. Nature 448:894-900.

Wilson RI, Nicoll RA (2002) Endocannabinoid signaling in the brain. Science 296:678-682.

Wokosin DL, Loughrey CM, Smith GL (2004) Characterization of a range of fura dyes with two-photon excitation. Biophys J 86:1726-1738.

Yin HH, Lovinger DM (2006) Frequency-specific and D2 receptormediated inhibition of glutamate release by retrograde endocannabinoid signaling. Proc Natl Acad Sci U S A 103:8251-8256.

Zhang L, Alger BE (2010) Enhanced endocannabinoid signaling elevates neuronal excitability in fragile $\mathrm{X}$ syndrome. J Neurosci 30: $5724-5729$.

Zimmer A, Zimmer AM, Hohmann AG, Herkenham M, Bonner TI (1999) Increased mortality, hypoactivity, and hypoalgesia in cannabinoid CB1 receptor knockout mice. Proc Natl Acad Sci U S A 96: $5780-5785$. 